\title{
PENGARUH PERCEIVED VALUE TERHADAP INTENTION TO COMPLY PENGUNJUNG MUSEUM NEGERI PROVINSI SULAWESI UTARA
}

\author{
Christine Patricia Elvano Porajow \\ Universitas Udayana, Unika Dela Salle Manado \\ Email: Porajowc336@gmail.com \\ Made Antara \\ Universitas Udayana \\ Email: antara_unud@yahoo.com \\ I Wayan Suardana \\ Universitas Udayana \\ Email: suar.dana@gmail.com
}

\begin{abstract}
The phenomenon of an increase in foreign tourist visitors in the North Sulawesi Province State Museum is an urgency factor to do this research as a form of evaluation of consumption patterns related to sustainable behavior when visiting, especially in crowded situations with low levels of supervision. The purpose of this study was to determine the extent to which visitor value consumption takes a role in museum sustainability through intention to comply. Primary research data obtained from questioners, observations, and interviews with the accidental sampling method on 100 respondents of foreign tourists. This research uses a quantitative approach SEM Smartpls 3.0 which is assessed through a Likert scale. The results of statistical data analysis show that motivation, consumer perceived value, and satisfaction significantly influence the intention to comply with foreign tourists on the rules in the museum and consumer perceived value is the dominant variable affecting satisfaction, therefore the museum is obliged to manage and facilitate consumption value through visitor perceptions museum.
\end{abstract}

Keywords: Museum visitor motivation, Consumer perceived value visitors, Museum visitor satisfaction, Intention to comply museum visitors 


\section{Pendahuluan}

Kajian akademik Hudson (1997) menemukan sulitnya mengelolah industri pariwisata museum untuk wisatawan mancanegara dikarenakan pengunjung museum memiliki dua kategori yaitu pertama pengunjung datang sekali seumur hidup dan yang kedua pengunjung biasanya adalah orang-orang yang tinggal cukup dekat dengan museum, sehingga mengunjungi museum menjadi kegiatan rekreasi rutin mereka. Faktanya Museum Negeri Provinsi Sulawesi Utara mengalami fenomena peningkatan dari tahun ke tahun.

Berdasarkan data statistik Provinsi Sulawesi Utara, sepuluh tahun terakhir tercatat tahun 2010 sampai dengan tahun 2019 jumlah kunjungan dari 180 menjadi 27.771 pengunjung terjadi trend peningkatan pada empat tahun terakhir. Lonjakan peningkatan terbesar terjadi pada tahun 2016 naik sebesar 2.547,69 persen kemudian tahun berikutnya sebesar 81,13 persen, selanjutnya sebesar 108,86 persen dan pada tahun 2019 naik sebesar 41,87 persen dari tahun sebelumnya. Situasi ini ternyata dipicu oleh kebijakan pemerintah Daerah Provinsi Sulawesi Utara bekerjasama dengan stakeholder lokal yang mengarahkan wisatawan rombongan asal China untuk mengunjungi museum.

Tabel 1. Wisatawan mancanegara yang berkunjung ke Museum Negeri Provinsi Sulawesi Utara

\begin{tabular}{lll}
\hline No. & Tahun & Jumlah wisatawan mancanegara \\
\hline 1. & 2010 & 290 \\
\hline 2. & 2011 & 171 \\
\hline 3. & 2012 & 155 \\
\hline 4. & 2013 & 150 \\
\hline 5. & 2014 & 175 \\
\hline 6. & 2015 & 195 \\
\hline 7. & 2016 & 5163 \\
\hline 8. & 2017 & 9.352 \\
\hline 9. & 2018 & 19.533 \\
\hline 10. & 2019 & 27.711 \\
\hline
\end{tabular}

Sumber: Data UPTD Museum Negeri Provinsi Sulawesi Utara 
Tabel 2. Kapasitas Museum

\begin{tabular}{|c|c|c|c|c|}
\hline Ruangan Pameran & Min & Max & Mean & Ket \\
\hline $\begin{array}{l}\text { Lantai 1: Peninggalan prasejarah (7 } \\
\text { rooms) }\end{array}$ & 8 & 15 & 11,5 & \multirow{2}{*}{$\begin{array}{l}\text { Not } \\
\text { include } \\
\text { lobby }\end{array}$} \\
\hline Lantai 2: Profesi masyarakat masa & & & & \\
\hline lampau & 8 & 15 & 11,5 & area \\
\hline$(4$ rooms $)$ & & & & \\
\hline Lantai 3: Seni, budaya, sejarah & & & & \\
\hline masyarakat SULUT (3 rooms) & 8 & 15 & 11,5 & \\
\hline Total & 23 & 45 & 34,5 & \\
\hline
\end{tabular}

Sumber: data primer (diolah) 2020

Rata-rata jumlah kunjungan wisatawan grup pada jadwal hari yang terjadwalkan 97,5 sehingga berdasarkan rata-rata daya dukung dan setiap jam 20 turis keluar dari museum maka museum ini dapat menangani sekitar 200 pengunjung dalam 6 jam kerja per hari sehingga museum masih relevan dengan jumlah fenomena kunjungan tersebut, meskipun faktanya gedung museum tidak termaintance dengan baik dan konsisten sehingga dapat berpengaruh pada kenyamanan pengunjung.

Dilematisnya upaya sustainability dalam framework museum salah satunya berasal dari pengunjung. Seperti dua sisi coin, banyaknya pengunjung menjadi motivasi pencapaian sustainable Pop (2016) tetapi disisi lain sikap wisatawan menjadi ancaman untuk sustainability karena masih ada orang yang tidak peduli bagaimana berperilaku yang pantas dengan memikirkan dampaknya pada lingkungan dan orang lain, sehingga hal ini mendukung penelitian Han Heesup dan Scan Hyun (2016) yang melihat sustainability museum melalui sikap pro lingkungan wisatawan. Fakta bahwa kondisi didalam area museum, uap nafas, keringat dan sentuhan kecil dari pengunjung saja dapat menjadi ancaman untuk koleksi karena kondisi rentannya. Situasi crowded museum, tingkat kelembaban ruangan dan suhu yang panas dapat ikut mengambil bagian, bahkan perilaku antusiasme-pun dapat mengacaukan 
tindakan seseorang dan menjadi ancaman terhadap koleksi museum, dan lebih mengkhawatirkan jika perilaku yang tidak bertanggungjawab itu adalah tindakan sengaja, ditambah lagi dengan rendahnya pengawasan dalam situasi crowded pengunjung. Poria (2001) melihat pengembangan pariwisata warisan budaya berkelanjutan teridentifikasi melalui dua konstruk yaitu motivasi dan persepsi pengunjung, dan studi Bramwell (2017) secara umum melihat sustainability pariwisata dan perilaku wisatawan harus melalui orientasi normatif, sikap yang terbentuk karena tekanan dari pihak luar, yang dalam hal ini adalah aturan-aturan yang berlaku (theory planned of behavior, Ajzen dan Fishbein, 1991).

Fenomena peningkatan pengunjung dan pola konsumsi wisatawan mancanegara yang berkunjung ke Museum Negeri Provinsi Sulawesi Utara merupakan alasan utama dilakukannya penelitian sebagai faktor urgensi yang wajib mendapat perhatian penuh dari museum dan pemerintah sebagai pembuat kebijakan. Adapun rumusan masalah penelitian ini adalah (1) Bagaimana karakteristik pengunjung mancanegara Museum Negeri provinsi Sulawesi Utara (2) Bagaimana tingkat motivation, consumer perceived value, satisfaction dan intention to comply pengunjung Museum Negeri Provinsi Sulawesi Utara (3) Bagaimana pengaruh faktorfaktor: a) Pengaruh motivation wisatawan mancanegara terhadap satisfaction ketika berkunjung ke museum, b) Pengaruh consumer perceived value wisatawan mancanegara terhadap satisfaction ketika berkunjung ke museum, c) Pengaruh satisfaction terhadap intention to comply wisatawan mancanegara di museum.

Minimnya penelitian untuk tujuan sustainability museum khususnya mengenai perilaku melindungi ataupun sebaliknya destructive masih merupakan area yang sangat luas dan kurang diteliti. Penelitian sebelumnya Han Heesup dan Sunghyup Sean Hyun (2016) telah mengklarifikasi faktor sikap pro lingkungan wisatawan terhadap sustainability museum, Pop, I., dan Borza, A (2016) juga mengklarifikasi 
bahwa pengunjung merupakan indikator utama dalam keberlanjutan museum, sedangkan peneliti dalam studi ini mengklarifikasi faktor nilai konsumsi pengunjung melalui intervening satisfaction berpengaruh significant terhadap intention to comply pengunjung pada aturan-aturan di museum sehingga memberi prediksi kontribusi niat perilaku terhadap sustainability behavior.

\section{Teori dan Metode}

Studi ini menggunakan beberapa teori yang mendukung gambaran besar tentang nilai konsumsi pengunjung museum yaitu theory museum quality, theory motivation, theory consumer perceived value, dan theory of planned behavior. Massimo Negri, 2009 menjelaskan bahwa theory museum quality memiliki dua kualitas yaitu kualitas publik yang merujuk pada pemenuhan kebutuhan, keinginan, kepuasan dan harapan konsumen/ pengunjung (Radder et al., 2011), (Maher et al., 2011), dan kualitas professional merujuk pada nilai konservasi dan penelitian (Pachucki, 2012). Dari kedua konsep besar tentang kualitas museum yang dijelaskan diatas dapat asumsikan bahwa variabel motivasi, costumer perceived value dan satisfaction adalah bagian yang mewakili public quality museum. Intention to comply wisatawan mancanegara adalah bagian dari tindakan konservasi yang mewakili professional quality museum.

Memahami perilaku konsumen wisatawan dapat dimulai dengan mengidentifikasi motivasi. Meurut Crompton 1979, wisatawan akan dihadapkan dengan pilihan destinasi wisata mana yang menjadi tujuannya dan hal ini disebut Travel Motivation. "Push " dan " Pull" lanjut beliau adalah faktor dan konsep kepentingan dalam membentuk motivasi, dimana push diidentifikasi sebagai faktor intangible yang mendorong seorang untuk melakukan perjalanan keluar jauh dari lingkungan tempat tinggal (rumah) sedangkan " Pull " adalah faktor karakteristik yang nyata dan bersifat provokatif yang menarik wisatawan ke arah destinasi tujuan. 
Jika motivasi lebih berbicara pada keterkaiatan emosional wisatawan maka sebaliknya variabel consumer perceived value lebih konsentrasi pada penilaian calon wisatawan terhadap kombinasi kualitas nilai secara keseluruhan produk, jasa dan harga sebagai tindakan menafsirkan informasi sehubungan dengan destinasi yang telah ditetapkan. Kombinasi nilai yang dimaksud tersebut sebagaimana dikemukakan oleh Sweeney dan Soutar (2010: pp 8) dimensi persepsi nilai konsumen terdiri dari empat aspek utama yaitu: emotional value, social value, performance-quality / functional value, dan price/monetary Value. Dalam penelitian ini keempat dimensi tersebut diinterpretasikan ke dalam variabel yang indikatornya disesuaikan dengan observasi dilapangan (pre-resaerch).

Inti dari teori perilaku terencana (theory of planned behaviour) mencakup 3 hal yaitu behavioral beliefs, normative beliefs dan control beliefs (Ajzen. 1991 dan Tang et al. 2011). Adapun yang menjadi acuan dari intention to comply dalam teori ini adalah normative beliefs, terkait persepsi seseorang yang terbentuk berdasarkan keinginan dan tekanan pihak lain. Pihak lain dalam hal ini dapat berasal dari orang-orang terdekat, lingkungan, aturan yang berlaku dan lain -lainnya yang berasal dari luar pribadi orang tersebut. Teori ini menjelaskan keterkaitan antara aturan- aturan yang ada dimuseum (normative beliefs) terhadap intention behavior sehingga hal inilah yang menjadi dasar penguatan penentuan indikator untuk intention to comply.

Penelitian berlokasi di Museum Negeri Provinsi Sulawesi Utara, dilakukan pada bulan Februari sampai Maret 2020. Data primer didapat melalui questioner, observasi dan wawancara dengan sampel sebanyak 100 responden wisatawan mancanegara melalui metode accidental sampling. Penentuan jumlah sample menggunakan referensi Hair dkk (2010) yang merekomendasikan jumlah sampel minimal lima (5) sampai sepuluh (10) kali dari jumlah indikator penelitian, dengan jumlah indikator sebanyak 20 x 5 maka didapatkan total sampel sebanyak 100 sampel. Analisis dinilai melalui 
skala likert lima poin dalam pendekatan kuantitatif SEM dengan software Smartpls 3.0 dan dijelaskan secara deskriftif.

\section{Hasil dan Pembahasan}

\section{Karakteristik Responden}

Responden dalam penelitian ini adalah wisatawan mancanegara yang berkunjung ke Museum Negeri Provinsi Sulawesi Utara pada periode Februari sampai dengan Maret 2020, dengan jumlah responden sebanyak 100 wisatawan.

Tabel 3. Distribusi Karakteristik Responden

\begin{tabular}{|c|c|c|}
\hline Karakteristik & Jumlah (Orang) & Persentase (\%) \\
\hline \multicolumn{3}{|l|}{ Jenis Kelamin } \\
\hline Laki-Laki & 44 & 44 \\
\hline Perempuan & 56 & 56 \\
\hline \multicolumn{3}{|l|}{ Umur } \\
\hline$<17$ Tahun & 2 & 2 \\
\hline 17-<25 Tahun & 11 & 11 \\
\hline 25- <35Tahun & 39 & 39 \\
\hline 35-<45 Tahun & 26 & 26 \\
\hline $45-<55$ Tahun & 14 & 14 \\
\hline 55-<65 Tahun & 8 & 8 \\
\hline \multicolumn{3}{|l|}{ Kebangsaan } \\
\hline Australian & 5 & 5 \\
\hline Chinese & 70 & 70 \\
\hline Dutch & 4 & 4 \\
\hline French & 2 & 2 \\
\hline German & 11 & 11 \\
\hline Japanese & 2 & 2 \\
\hline Singapore & 5 & 5 \\
\hline Swiss & 1 & 1 \\
\hline \multicolumn{3}{|l|}{ Pekerjaan } \\
\hline Business & 15 & 15 \\
\hline $\mathrm{CS}$ & 6 & 6 \\
\hline Guide & 6 & 6 \\
\hline Housewife & 2 & 2 \\
\hline OB & 5 & 5 \\
\hline Profesional & 24 & 24 \\
\hline
\end{tabular}




\begin{tabular}{lll}
\hline Karakteristik & Jumlah (Orang) & Persentase (\%) \\
\hline Retired & 7 & 7 \\
\hline Student & 10 & 10 \\
\hline Tailor & 25 & 25 \\
\hline Jumlah Kunjungan & & \\
\hline 1 kali & 93 & 93 \\
\hline 2 kali & 0 & 0 \\
\hline 3 kali & 1 & 1 \\
\hline$>3$ kali & 6 & 6 \\
\hline Pasangan berkunjung & & \\
\hline Teman & 73 & 73 \\
\hline Keluarga & 20 & 20 \\
\hline Sendiri & $\mathbf{7}$ & $\mathbf{7}$ \\
\hline Jumlah & $\mathbf{1 0 0}$ & $\mathbf{1 0 0}$ \\
\hline
\end{tabular}

Sumber: Data Penelitian Tahun 2020

Data diatas menjelaskan pengunjung perempuan lebih banyak dari lelaki, ratarata usia wisatawan yang berkunjung adalah usia produktif, diungguli sedikit oleh pekerja blue-collar 42 persen dan white-collar 39 persen. Jumlah kunjungan pertama kali mendoninasi 93 persen dengan berkunjung bersama teman 73 persen dan didominasi wisatawan Asia sebanyak 77 persen.

\section{Hasil Uji Vaiditas dan Realibilitas}

Kriteria dalam teknik analisa data SmartPLS yang dilakukan untuk uji validitas ditunjukkan oleh Tabel 4 pada halaman berikut, dimana nilai loading factor semua indikator dinyatakan valid dengan rentang nilai 0,748 sampai dengan 0,969 sehingga tidak ada indikator yang dieliminasi. Hal ini mengklarifikasi bahwa instrumen penelitian dengan pertanyaan mampu merefleksikan konstruk yang digunakan. Demikian halnya dengan hasil uji realibilitas melalui nilai cronbach's alpha dengan hasil rentang nilai 0,765 sampai dengan 0,965 sehingga menunjukkan konsistensi item pertanyaan-pertanyaan yang digunakan. 
Tabel 4. Hasil Uji Validitas dan Realibilitas

\begin{tabular}{|c|c|c|c|}
\hline Variabel & Indikator & Loading Factor & Cronbach's Alpha \\
\hline \multirow[t]{4}{*}{ Motivation } & $\mathrm{X} 1.1$ & 0,969 & \multirow{4}{*}{0,765} \\
\hline & $\mathrm{X} 1.2$ & 0,945 & \\
\hline & $\mathrm{X} 1.3$ & 0,917 & \\
\hline & $\mathrm{X} 1.4$ & 0,969 & \\
\hline Consumer & $\mathrm{X} 2.1$ & 0,965 & \multirow{7}{*}{0,963} \\
\hline \multirow[t]{6}{*}{ Perceived Value } & $X 2.2$ & 0,947 & \\
\hline & $X 2.3$ & 0,867 & \\
\hline & $X 2.4$ & 0,829 & \\
\hline & $X 2.5$ & 0,853 & \\
\hline & $X 2.6$ & 0,910 & \\
\hline & $\mathrm{X} 2.7$ & 0,965 & \\
\hline \multirow[t]{4}{*}{ Satisfaction } & Y1.1 & 0,784 & \multirow{4}{*}{0,965} \\
\hline & $\mathrm{Y} 1.2$ & 0,761 & \\
\hline & Y1.3 & 0,748 & \\
\hline & Y1.4 & 0,769 & \\
\hline \multirow{5}{*}{$\begin{array}{l}\text { Intenteion to } \\
\text { comply }\end{array}$} & $\mathrm{Y} 2.1$ & 0,877 & \multirow{5}{*}{0,926} \\
\hline & $\mathrm{Y} 2.2$ & 0,875 & \\
\hline & $Y 2.3$ & 0,887 & \\
\hline & Y2.4 & 0,819 & \\
\hline & Y2.5 & 0,933 & \\
\hline
\end{tabular}

Sumber: Data Penelitian Tahun 2020

Tabel 5 mengklarifikasikan bahwa model dinyatakan telah memenuhi kriteria/fit jika nilai SRMR <0,10 dan dinyatakan perfect fit jika nilai SRMR $<0,08$. Berdasarkan tabel diatas dapat diketahui bahwa nilai GOF dari penelitian ini sebesar 0,053 maka dapat dikatakan model ini perfect fit dan layak untuk dilanjutkan ke hipotesis. 
Tabel 5. Nilai GOF

\begin{tabular}{lcc}
\hline & Saturated Model & Estimated Model \\
\hline SRMR & 0,053 & 0,065 \\
\hline$d \_U L S$ & 0,589 & 0,894 \\
\hline$d \_G$ & 1,863 & 1,991 \\
\hline Chi-Square & 636,560 & 659,234 \\
\hline NFI & 0,786 & 0,779 \\
\hline Sumber: data hasil penelitian dilapangan (diolah) 2020
\end{tabular}

Sumber: data hasil penelitian dilapangan (diolah) 2020

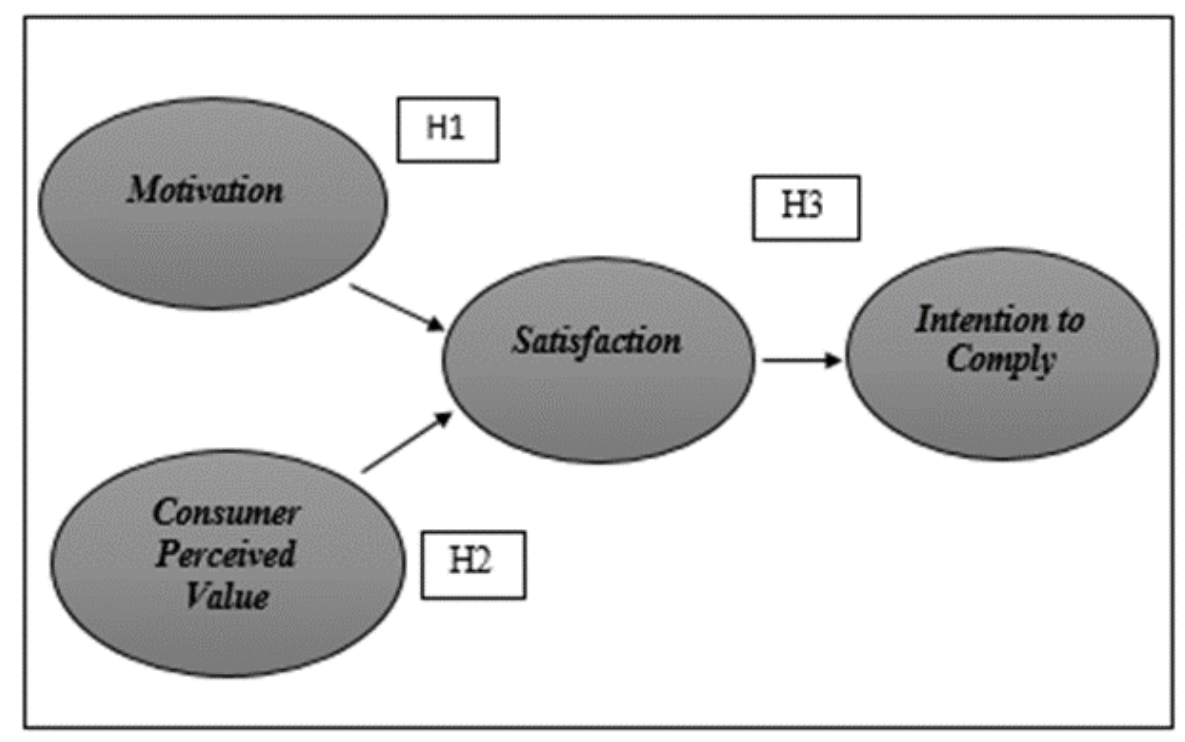

Gambar 1. Kerangka Konseptual Penelitian 
Tabel 6. Direct effect dan Pengujian Hipotesis

\begin{tabular}{llllll}
\hline V.Ekso > V. Endo & $\begin{array}{c}\text { Original } \\
\text { Sample }\end{array}$ & $\begin{array}{c}\text { Standar } \\
\text { Deviasi }\end{array}$ & T-Statistics & -value & Kesimpulan \\
& 0,764 & 0,047 & 15,763 & 0,000 & H1 Diterima \\
$\begin{array}{l}\text { Motivation } \\
\text { terhadap } \\
\text { satisfaction }\end{array}$ & & & & & \\
\hline $\begin{array}{l}\text { Consumer Perceived } \\
\text { value terhadap } \\
\text { satisfaction }\end{array}$ & 0,235 & 0,026 & 4,569 & 0,000 & H2 Diterima \\
\hline $\begin{array}{l}\text { Satisfaction } \\
\text { terhadap intention } \\
\text { to comply }\end{array}$ & 0,721 & 0,050 & 26,998 & 0,000 & H3 Diterima \\
\hline
\end{tabular}

Studi ini mengajukan tiga hipotesis yang didasarkan pada observasi fenomena dilapangan dengan pendekatan teoritis perilaku intention to comply pengunjung museum dalam konteks sustainability museum, terkait teori museum quality. Pengujian hipotesis dilakukan dengan t-statistics untuk pengujian pengaruh langsung sesuai dengan ketentuan jika nilai $t$-statistics lebih dari 1,96 dan taraf signifikansi $5 \%(0,05)$ maka Ho ditolak dengan nilai $p$-value $<0,05$ atau hipotesis diterima.

Uji Hipotesis I, hasil menunjukkkan variabel motivation berpengaruh significant terhadap satisfaction dengan original sample 0,235 dan nilai t-statistics 4,569 serta p-value 0,000. Maka sesuai ketentuan hipotesis diterima. Uji Hipotesis II, hasil menunjukkan bahwa variabel consumer perceived value berpengaruh significant terhadap variabel satisfaction dengan original sample 0,764 dengan nilai t-statistics sebesar 15,763 dan nilai p-value 0,000. Maka sesuai ketentuan hipotesis diterima. Uji Hipotesis III, hasil menunjukkan bahwa konstruk satisfaction berpengaruh significant terhadap intention to comply dengan original sampel 0,721 dengan t-statistics sebesar 26,998 dan nilai $p$ value 0,000 . Maka hipotesis diterima. 


\section{Pengaruh Faktor-Faktor}

\section{Pengaruh Motivation terhadap satisfaction}

Hasil analisis data secara statistik menginformasikan bahwa atribut motivation berpengaruh signifikan terhadap satisfaction melalui koefisien jalur sebesar 0,235 dan t-statistic dengan nilai sebesar 4,569 dan bukti ini merujuk pada motivation yang tinggi akan mengarah pada satisfaction wisatawan mancanegara yang tinggi. Keempat indikator yang diajukan semuanya diterima karena memiliki nilai outer loading diatas 0,7, dengan nilai antara 0,917 sampai dengan 0,969 dan signifikansi ini secara empiris menyatakan motivation berpengaruh pada satisfaction wisatawan mancanegara yang berkunjung ke Museum Negeri Provinsi Sulawesti Utara. Hasil penelitian ini bersesuaian dengan penelitian yang dilakukan oleh Brida, et al (2013) yang menyatakan bahwa faktor yang mempengaruhi kepuasan heritage tourist khususnya wisatawan mancanegara berasal dari motivasi dikarenakan mengisi waktu luang memberi asumsi kesiapan berwisata sehingga semakin jauh jarak antara tempat tinggal dan tempat yang akan dikunjungi maka semakin tinggi tingkat satisfaction berkunjung yang diperolehnya.

\section{Pengaruh consumer perceived value terhadap satisfaction}

Analisis data menyatakan consumer perceived value signifikan berpengaruh terhadap satisfaction wisatawan mancanegara dengan nilai loading factor 0,764 dan $t$ statistic sebesar 15,763 maka consumer perceived value yang tinggi akan mengarah pada satisfaction wisatawan yang tinggi. Ketujuh indikator pembentuk variabel consumer perceived value diterima karena memiliki nilai outer loading diatas 0,7 dengan bentangan nilai antara 0,829 sampai dengan 0,965 sehingga tidak ada yang dieliminasi. Hasil penelitian ini sejalan dengan studi Rasoolimnaesh et al (2016), Kusujniatiun dan Winsmawati (2011), Jin et al (2013), Chen (2010) yang menyuarakan 
bahwa semakin tinggi nilai yang dipersespsikan oleh wisatawan heritage semakin tinggi level kepuasan yang mereka miliki.

\section{Pengaruh satisfaction terhadap intention to comply}

Penelitian data secara statistik menghasilkan satisfaction berpengaruh signifikan terhadap intention to comply, dibuktikan melalui outer loading 0,721, dan $t$ - statistic 26,998 , sehingga satisfaction yang tinggi akan mengarah pada intention to comply yang tinggi. Berikut adalah detail penjelasan efek satisfaction terhadap masing-masing indikator dari variabel intention to comply.

\subsection{Pengaruh satisfaction terhadap "I plan for not smoke in the museum exhibition area"}

Hasil nilai loading yang didapatkan melalui analisis outer model smartpls dari indikator sebesar 0,877 maka secara empiris significant dan menjamin tingkat signifikansi nilai mean indikator dengan nilai rata-rata 4,20 yang tergolong kategori tinggi. Hal ini selaras dengan fakta dilapangan dimana wisatawan mancanegara yang berkunjung ke museum perilakunya tergolong cukup patuh pada aturan "do not smoke" dan berdasarkan observasi juga terlihat kesadaran dari pengunjung perokok yang ketika terlanjur merokok karena menunggu antrian masuk, mereka akan memadamkan rokoknya untuk mengikuti museum tour ketika sudah tiba giliran masuk. Jika ditemukan ada pengunjung yang merokok dengan tidak sengaja misalnya dengan alasan tidak mengetahui aturan ataupun dengan tindakan sengaja karena benar-benar ingin merokok dalam waktu yang terjepit karena di bus dilarang merokok, pihak museum tentunya akan memberikan teguran sebagaimana diutarakan dalam wawancara bersama kepala seksi museum.

Hasil nilai Inner model loading motivation terhadap satisfaction $(0,235)$ dan nilai consumer perceived value terhadap satisfaction $(0,764)$ telah menjadikan konstruk kedua variabel endogen tersebut berpengaruh secara significant, sehingga akumulasi nilai 
sikap kedua variabel laten yang membentuk satisfaction akan menstimulasi niat untuk patuh pengunjung pada aturan museum.

\subsection{Pengaruh satisfaction terhadap "I plan for not eat in the museum exhibition area"}

Signifikasi indikator dikonfirmasi oleh loading outer model indikator dengan nilai sebesar 0,875 , demikian halnya dengan nilai mean indikator 4,30 yang berarti masuk dalam kategori tinggi untuk total jawaban reponden dan mendukung signifikansi indikator ini. Realita dilapangan menunjukkan perilaku pengunjung museum tergolong patuh pada aturan "do not eat in the museum" yang diberlakukan museum sehingga bersinergi dengan hasil observasi yang menunjukkan adanya kesadaran pengunjung akan aturan museum dengan tidak melakukan aktivitas makan di area pameran selama tur museum. Hal ini juga didukung oleh tindakan preventif pihak museum dengan diberlakukannya aturan tidak diizinkan membawa tas besar untuk pengunjung yang usianya masih berada dalam pengawasan orang dewasa, sebagaimana hasil wawancara dengan pihak museum.

Loading motivation terhadap satisfaction $(0,235)$ dan nilai consumer perceived value terhadap satisfaction $(0,764)$ telah menjadikan kedua konstruk berpengaruh secara significant dalam inner model, sehingga representasi nilai sikap motivation dan consumer perceived value melalui satisfaction menstimulasi sikap pengunjung museum dengan niat untuk patuh pada aturan museum.

\subsection{Pengaruh satisfaction terhadap "I plan for not drink in the museum exhibition area"}

Indikator "I plan norot drink in the museum" terbukti telah memenuhi nilai ideal variabel laten dengan nilai sebesar 0,887 , demikian halnya dengan nilai mean indikator 4,29 yang merujuk pada kategori tinggi sehingga mendukung signifikansi indikator 
ini. Fakta dilapangan bahwa pengunjung museum tergolong patuh pada aturan "do not drink in the museum" sesuai dengan hasil observasi yang menunjukkan adanya kesadaran wisatawan yang mendukung aturan tersebut dengan tidak melakukan aktivitas minum dimuseum apalagi jika melakukan aktivitas minum didekat koleksi dan hal ini juga tidak terlepas dari tindakan preventif diambil sesuai dengan hasil percakapan dengan pihak museum.

Hasil hubungan inner model dengan nilai loading motivation terhadap satisfaction sebesar 0,235 dan nilai consumer perceived value terhadap satisfaction sebesar 0,764 menjadi acuan secara empiris intervening satisfaction terhadap intention to comply yang significant terhadap indikator "Do not drink in the museum". Variabel satisfaction mampu menstimulasi sikap niat untuk patuh pengunjung pada aturan yang berlaku.

\subsection{Pengaruh satisfaction terhadap "I plan for not touch a collection that is prohibited from touching"}

Dengan nilai sebesar 0,875, membuktikan bahwa indikator ini adalah significant, begitupun dengan nilai mean indikator 4,30 yang berada pada kategori tinggi dan mendukung signifikansi indikator ini. Bukti dilapangan juga menunjukkan pengunjung museum memiliki perilaku yang taat pada peraturan "Do not touch collection", sejalan dengan upaya tindakan preventif yang dilakukan pihak museum yaitu memajang sebagian besar koleksi dalam etalase kaca. Treatment melindungi koleksi dengan bahan kimia menjadi tujuan utama melindungi koleksi dan pengunjung, sebagaimana hasil interview dengan kepala seksi museum. Hasil observasi juga mendukung fakta adanya kesadaran dari pengunjung dengan tidak menyentuh koleksi-koleksi yang dilarang untuk disentuh meskipun tidak dapat menjamin bahwa tidak ada pelanggaran situasional mengingat tingkat pengawasan yang rendah di museum dengan tidak adanya kamera pengawas ataupun petugas 
yang incharge dalam tur museum selain tour guide wisatawan dan ditambah lagi dengan kondisi museum yang berlantai 3 dengan banyak ruangan.

Nilai loading motivation terhadap satisfaction sebesar 0,235 dan consumer perceived value terhadap satisfaction sebesar 0,764 menjadi bukti empiris signifikasinya dan akumulasi nilai sikap motivation dan consumer perceived value yang membentuk satisfaction mampu menstimulasi niat untuk taat pengunjung pada aturan museum.

\subsection{Pengaruh satisfaction terhadap "I plan for contribute financially as requested by museum"}

Outer loading indikator sebesar 0,875, didukung oleh nilai mean indikator sebesar 4,30 masuk dalam kategori tinggi, memperkuat signifikansi indikator ini. Realita dilapangan pun menunjukkan pada umumnya pengunjung museum tergolong respect dengan mengikuti aturan untuk berpartisipasi finansial, sesuai hasil observasi pada umumnya pengunjung mengikuti instruksi museum untuk berkontribusi dengan menyisihkan uang pada kotak partisipasi. Meskipun besarnya niat partisipasi tidak sebanding dengan nilai nominalnya dikarenakan bentuk partisipasi adalah instruksi. Kondisi ini sesuai dengan hasil sharing dengan staff museum yang mengidentifikasi bentuk sikap partisipasi pengunjung dalam level yang berbeda-beda dengan bentangan nilai nominal Rp.5000 sampai dengan Rp.20.000 dan dalam mata uang china dalam pecahan satu yuan.

Outer loading motivation terhadap satisfaction sebesar 0,235 dan nilai consumer perceived value terhadap satisfaction 0,764 membuktikan satisfaction adalah intervening yang significant terhadap indikator ini. Variabel satisfaction memprovokasi sikap niat untuk patuh pengunjung dengan ikut berpartisipasi secara finansial meskipun hasil menunjukkan bahwa nilai sikap berbanding terbalik dengan nilai nominal partisipasi. 
Terkait hasil tingkat intention to comply pengunjung museum dengan hasil analisis outer model pls yang menunjukkan perbedaan leading dan lowest indikator. Hal ini dapat dijelaskan bahwa hasil nilai mean selain merupakan jawaban dari sudut pandang wisatawan terhadap peraturan museum, sikap indikator tersebut adalah gambaran kebutuhan primer dan sekunder pengunjung (minum dan merokok), dilakukan oleh siapapun, dimanapun, dapat dengan mudah dilakukan sekaligus dapat dengan mudah untuk dilanggar ketika berhadapan dengan aturan. Adapun penjelasan mengenai hasil outer loading pls, dapat dijelaskan bahwa kedua indikator leading (partisipasi finansial pengunjung) maupun lowest (aturan menyentuh koleksi) mewakili sudut pandang museum, sebuah tuntutan museum kepada pengunjung dikarenakan kondisi ART museum yang belum mandiri masih bergantung pada anggaran pemerintah dan issue global museum yang terus ada dari waktu ke waktu terkait pengunjung dan koleksi.

Dalam penelitian ini intention to comply mengukur sikap wisatawan terhadap aturan-aturan yang berlaku di museum meskipun masih dalam berbentuk niat perilaku belum merupakan tindakan aktual sehingga membutuhkan kajian studi yang menguatkan bahwa niat perilaku memiliki andil dalam tindakan. Azwar (2013) mengatakan bahwa wisatawan bisa saja bersikap positif terhadap aturan pengunjung tetapi masih dapat melakukan pelanggaran dikarenakan motif dan faktor-faktor situasional dan untuk meminimalisir pelanggaran direkomendasikan tiga hal yaitu mengubah perilaku pengunjung, mengubah lingkungan dan menambah pengetahuan baru. Jika dilihat ketiga saran ini adalah bagian yang dapat diusahakan diawal sebagai tujuan mencapai sustainablility behavior museum dan dibagian akhir sebagai instrument untuk mencapai satisfaction wisatawan, sehingga dapat dikatakan siklus dimana satisfaction berperan sebagai intervening akan dapat memaknai niat patuh (intention to comply) pada sikap aktual pengunjung. Bagian ini juga didukung oleh theory planned of behavior Azjen (1991) yang menunjukkan model riset bahwa 
intention memiliki kecenderungan yang besar terhadap perilaku aktual (behavior), sehingga dengan mengetahui niat patuh pengunjung setidaknya ada gambaran untuk museum mengusahakan niat ini menjadi perilaku aktual melalui satisfaction.

\section{Simpulan dan Saran}

Hasil penelitian menunjukkan (1) Pengunjung perempuan lebih banyak dari lelaki, usia produktif sebanyak 39 persen, pekerja blue-collar 42 persen. Jumlah kunjungan pertama kali ke museum 93 persen, bersama teman 73 persen dan 77 persen pengunjung museum Asia, (2) Motivation wisatawan mancanegara berpengaruh signifikan terhadap satisfaction (koefisien jalur 0,235 dan nilai $t$-statistics 4,569); consumer perceived value berpengaruh signifikan terhadap satisfaction (koefisien jalur 0,764 , nilai $t$-statistics 15,763 ) dan satisfaction berpengaruh signifikan terhadap intention to comply (koefisien jalur sebesar 0,721 dengan nilai t-statistics 26,998).

Saran dari penelitian ini untuk museum (1) Nilai persepsi konsumen merupakan variabel yang dominan mempengaruhi kepuasan wisatawan, karenanya museum wajib mengelola nilai konsumsi wisatawan melalui persepsi wisatawan, (2) Satisfaction wisatawan terbukti mempengaruhi niat untuk patuh pada aturan di museum, karenanya museum wajib memfasilitasi terciptanya kondisi museum public quality. Untuk pemerintah (1) Revitaslisasi museum untuk mengubah wajah cleanliness / hygiene museum sekaligus mendukung daya tampung koleksi dan

pengunjung, (2) Evaluasi kebijakan mendatangkan wisatawan wajib berdasarkan pada konsep museum quality sehingga kebijakan akan bersinergi dengan framework sustainability museum. 
Pengaruh Perceived Value Terhadap Intention to Comply Pengunjung Museum Negeri...

\section{Ucapan Terimakasih}

Terimakasih setulusnya kepada Pembimbing I Prof. Dr. Ir. Made Antara, MS dan Pembimbing II Dr. I Wayan Suardana STT.Par., M.Par atas semua bimbingan, arahan dan saran teknis yang membangun konstruk dan isi artikel ini. Terimakasih juga penulis sampaikan kepada tim penguji diantaranya Dr. I Putu Gde Sukaatmadja, SE, MP, Dr. Putu Saroyini Piartrini., SE., MM., AK, dan Dr. Made Heny Urmila Dewi, SE., M.Si atas semua kritik, koreksi dan saran untuk penyempurnaan artikel ini.

\section{Daftar Pustaka}

Baj Irena Pandža, 2015. "Tourist Perceived Value, Relationship to Satisfaction, and Behavioral Intentions: The Example of the Croatian Tourist Destination Dubrovnik. Journal of Travel Research". Vol. 54, No. 1. pp $122-134$.

Bramwell Bill et al. 2017. "Twenty-five years of sustainable tourism and the Journal of Sustainable Tourism: looking back and moving forward. Journal of sustainable tourism". Vol.25, No. 1, pp. 1-9.

Brida Juan Gabriel, Marta Disegna, Tsvetina Vachkova. 2013. "Visitor satisfaction at the museum: Italian versus foreign visitors". Tourism Preliminary Communication. Vol. 61, No. 2, pp. 167-186.

Byrd, E. T. 2007. "Stakeholders in Sustainable Tourism and Their Role: Applying Stakeholder Theory to Sustainable Development". Tourism Review, Vol.62, No. 2, pp. 6-13.

Chen, Ching $\mathrm{Fu}$ and $\mathrm{Chen}, \mathrm{Fu}$ Shian. 2010. "Experience quality, perceived value, satisfaction and behavioral intentions for heritage tourists". Tourism Management. Vol. 31, No.1, pp. 29-35.

Cohen, Louise. Lawrence, Monion. Keith Morrison. 2007. "Research Methods in Education Sixth Edition". New-York: Routledge

Dhankhar Dinesh, Lakhvinder Singh. 2014. "An Analysis Of Tourist Satisfaction And Desitnation Loyality: A Study Of Sri Krishna Museum In Kurushetra." Journal of Kashmir for Tourism and Catering Technology. Vol. 1, No. 2.

Ghozali, I. 2014. "Aplikasi Analisis Multivariate dengan Sess". Cetakan Keempat. Semarang: Badan Penerbit Universitas Diponegoro. 
Han Heesup dan Sunghyup Sean Hyun. 2016. “Fostering customers' pro-environmental behavior at a museum". Article in Journal of Sustainable Tourism. Vol. 25, No. 9, pp. 1240-1256.

Hair, J. F. 2010. “Multivariate Data Analysis, $7^{\text {th }}$ Edition”. New York: Prentice Hall International, Inc

Kamal Mostafa, Pramanik Shah A. K. 2015. "Identifying Factors Influencing Visitors to visit museum in Bangladesh and setting Marketing Strategies for Museum". Journal of Business and Management. Vol. 17, No. 10, pp. 85-92

Mahyarni. 2013. "Theory Of Reasoned Action and Theory Of Planned Behavior (Sebuah Kajian Historis tentang Perilaku"). Jurnal El-Riyasah. Vol. 4, No. 1.

Munandar A, Perdana A, Rahayu A, Gultom A. 2011. "Sejarah Permuseuman di Indonesia". Jakarta: Direktorat permuseuman

Negri, M., Niccolucci, F., Sani, M. 2009. "Quality in museums". Budapest: Archaeolingua.

Pop Izabela Luiza and Anca Borza. 2016. "Quality in museums as a way to increase sustainability". European Journal of Sustainable Development. Vol. 5, No. 3. pp. 217-228.

Pachucki, M.C. 2012. “Classifying quality: Cognition, interaction, and status appraisal of art museums". Poetics, Vol. 40, pp. 67-90.

Simpson, K. (2000). "Customer Satisfaction and Behavioural Intentions in a Rural Community Museum Environment". Journal of Quality Assurance in Hospitality \& Tourism. Vol. 1, No. 3, pp. 1-27.

Sugiyono. 2008. "Metode Penelitian Kuantitatif Kualitatif dan RED". Bandung: Alfabeta

Sweneey Jillian C, Geoffrey N. Sautar. 2001. “Consumer Perceived Value: The development of multiply item Scale". Jurnal of Retailing. Vol 77, pp 203-220.

Zauner Alexander, Monika Koller dan Isabella Hatak. 2015. “Customer perceived value-Conceptualization and avenues for future research". Cogent Psychology. Vol. 2, No. 1. 
Pengaruh Perceived Value Terhadap Intention to Comply Pengunjung Museum Negeri...

\section{Profil Penulis}

Christine Patricia Elvano Porajow adalah alumnus Program Studi Magister Pariwisata (S2) di Fakultas Pariwisata Universitas Udayana Denpasar, TA 2018/2020. Sebelumnya penulis memulai pendidikan dibidang pariwisata dengan menyelesaikan Diploma III, Jurusan Perhotelan di Akademi Pariwisata Manado (AKPAR) dan menyelesaikan program sarjana melalui jalur vokasional Diploma IV di Sekolah Tinggi Ilmu Pariwisata Manado tahun 2011.

I Made Antara adalah guru besar Fakultas Pertanian Udayana, kelahiran Singaraja 25 Desember 1954. Beliau mengajar di Jurusan Sosial Ekonomi Pertanian Fakultas Pertanian (P.S Agribisnis) dan diprodi lain seperti Program Studi Magister Pariwisata, dan Program Doktor Pariwisata, Program Magister Ilmu Lingkungan, dan Program Doktor Kajian Budaya Universitas Udayana.

I Wayan Suardana adalah dosen Fakultas Pariwisata Universitas Udayana, kelahiran Panggung 1 Februari 1979. Beliau mengajar di Prodi S1 Industri Perjalanan Wisata Fakultas Pariwisata dan Prodi S2 Pariwisata Unud. Beliau juga menjabat sebagai wakil dekan I pada Fakultas Pariwisata Unud. 